\title{
MEASURING METHODS OF THE CORPORATE COMPETITIVENESS, AND THOSE WEAKNESSES
}

\author{
Nagy Tunde Orsolya \\ University of Debrecen, Hungary \\ nagy.tunde@econ.unideb.hu \\ Darabos Eva \\ University of Debrecen, Hungary \\ Labas Istvan \\ University of Debrecen, Hungary
}

(Received October 2015; accepted February 2016)

\begin{abstract}
This treatise was carried out with the aim of giving the reader an overview of different conceptual approaches of the competitiveness. It particularly deals with the competitiveness according to the "practical" approach, "environmental/system" approach, "capital reorganisation" approach and with the widely accepted closed definitions of competitiveness. To determine the components of competitiveness according to different aspects, to assess some empirical examinations regarding the analysis of the aforementioned aspects as well as to present the results of an own primer research are also important parts of the treatise.
\end{abstract}

Keywords: corporate competitiveness, SME sector, competitiveness measurement

\section{Introduction}

In the last two decades, examining the micro-level competitiveness of enterprises and the macro-level competitiveness of bigger geographical units has become a widely researched topic from both theoretical and practical point of view. Examining the competition as a successful fight for the scarce resources is essentially as old as mankind. However, the focus has been put on the competitiveness as an examination from the point of view of corporate governance only since the 1980s. There is a much cited fact that even the word 'competitiveness' was not written in the significant external trade works of the preceding period. The theoretical and practical researches have started from more sides and a kind of rapprochement of the trends looms only nowadays. Most of the researchers regard the competitiveness as a microeconomic category i.e. which can primarily be interpreted at corporate level as well as product level. Nowadays, more and more people emphasize the importance of the SME sector's competitiveness, but in practice, such models are still not made which would be specialized for measuring the competitiveness of small- and medium-sized companies. Generally, the corporate competitiveness is examined by means of the 
criteria set developed by the same competitiveness definition, not focusing on the specific features of SMEs.

\section{Interpretation of the competitiveness}

Many people define the competitiveness in many ways; there is still no unified definition which is accepted by everyone. More overall works can be found about the issue of defining the competitiveness. The largest consensus among the authors shows itself in the fact that the definitions can be applied to the different level of competitiveness. For example, Gyula Horvath has worded the competitiveness in three ways:

- According to the "practical" approach, the competitiveness means the capacity of companies to adapt, how they are able to take over the technical and organizational solutions being successful elsewhere i.e. the "best practice" (benchmarking). In this case, the competitiveness of the region and the country depends on the adaptation capacities of the companies operating there.

- According to the "environmental/system" approach, competitiveness means how the company is able to optimize the elements of its economic environment i.e. its economic base (capital and label markets, quality of inputs, infrastructure). In this case, that region or country is competitive which can provide the necessary high quality economic base for the dominant industries, companies operating there.

- According to the "capital development" approach, competitiveness means how a company or sector is able to accumulate the human capital and physical capital and to improve technology. A region or country is competitive only if it attracts the investments and creation of such new production establishments and service-providing activities which are relating to big, mainly international corporations (Horvath, 2001).

Insofar as we wish to go deeper into the different competitiveness definitions, it is required to segregate three levels of the determination:

- The first level is when we define the concept of competitiveness shortly, briefly as wells as closed in one sentence and, for example, we speak about the ability to cope.

- The second level is when we explain what factors could compose the statements in the definition, for example, the ability to cope could mean the increase of market share or a profit rate being higher than the industry average.

- And, at the third level, we can speak about opportunities to observe and measure, for example, what particular rate we regard as profit rate. 


\section{Closed definitions of the competitiveness (first level)}

The authors obtain different results not only based on different assumptions but there is still no unified standpoint in the questions of at what level and about whose competitiveness it makes sense to consult. Its natural consequence is that the different standpoints are about different levels of competitiveness being incomparable, from the micro level through the regional level to the global one. It is not clarified whether the different levels have effect on each other and, if they do, what kind it can be. In the widest sense, the literature separates 4 levels of competitiveness (Meyer-Stamer, 2008):

- The corporate-level competitiveness examinations measure the performance of a particular corporation. The concern is caused by the heterogeneity of corporate level, namely the grab for different attributes of big companies and the sector of small- and medium-sized companies (SME), and then the problem of relation with the higher levels arises almost immediately. The micro level is where the companies are competing on competitive markets and are establishing networks and associations with each other in order to maintain their competitive advantage.

- The regional level means a level being smaller than a country according to the domestic interpretation. At mezo level, such targeted interventions are carried out which support the efforts of companies to elaborate their competitive advantage.

- In the empirical examinations, the national level is the most widespread and it needs the least explanation. There are general institutions, economic policies and demand conditions at macro level.

- The European Blue Banana can be mentioned as an example for the level of the above-mentioned countries (Schatzl, 1993). There are the basic orientations of a given society and factors changing slowly are at meta level.

In the specialized literature, three authors have created such definitions concerning the corporate, regional and national level which are widely accepted; the most important buzzwords of these ones are shown by table (1.).

Table 1. Closed definitions concerning more levels of the competitiveness

\begin{tabular}{|c|l|}
\hline Creator of definition & \multicolumn{1}{c|}{ The most important buzzwords } \\
\hline Adam Torok & $\begin{array}{l}\text { - ability to obtain position in the competition } \\
\text { - ability to cope in the competition }\end{array}$ \\
\hline OECD & $\begin{array}{l}\text { - factor income } \\
\text { - level of employment } \\
\text { - sustainable base }\end{array}$ \\
\hline Porter M. E. & $\begin{array}{l}\text { - those institutions, policies and factors which determine the } \\
\text { productivity }\end{array}$ \\
\hline
\end{tabular}

Source: Own edition, based on (Torok, 1999; Lengyel, 1999; Porter - Swab, 2008) 
Adam Torok words that "...the concept of competitiveness at micro level means the ability to obtain position in the market competition and the ability to cope among the companies, competitors of each other as well as national economies from macroeconomic point of view" (Torok, 1999). According to OECD, the competitiveness is "an ability of regions above the companies, industries, regions and nations to produce a relatively high factor income and a relatively high level of employment on a sustainable base, under international competition conditions" (Lengyel, 1999:13). And, Porter M. E. defines the competitiveness as a totality of such institutions, policies and factors which determine the level of productivity of a country, company" (Porter - Swab, 2008). Table 2 contains the most important buzzwords of definitions concerning the corporate competitiveness exclusively.

Table 2. Closed definitions concerning the corporate competitiveness exclusively

\begin{tabular}{|c|c|}
\hline Creator of definition & The most important buzzwords \\
\hline European Union & $\begin{array}{l}\text { - can be sold on the international market } \\
\text { - high and sustainable incomes }\end{array}$ \\
\hline Laszlo Csorba & $\begin{array}{l}\text { - takes part in the competition } \\
\text { - strives to reach its own goals }\end{array}$ \\
\hline Laszlo Csaba & - represents a forward-looking value judgement \\
\hline Erzsebet Czako & $\begin{array}{l}\text { - in case of the products of competitors [...] they are more willing to } \\
\text { pay for it under conditions ensuring profit for the company } \\
\text { - is able to sense the environmental changes and the changes within } \\
\text { the corporation as well as the accommodation to them }\end{array}$ \\
\hline
\end{tabular}

Source: Own edition, based on (Csorba, 2009; Csaba, 2008; Czako, 2005)

Among the definitions especially aimed at the corporate competitiveness, there is one by far the most accepted by Erzsebet Czako, according to which "it is an ability of the corporation to be able to provide such products and services for the consumers permanently, by complying with the standards of social responsibility, which the consumers are willing to pay for rather than for the products (services) of competitors, under conditions ensuring profit for the company. The condition of this competitiveness is that the company shall be able to sense the environmental changes and the changes within the corporation as well as the accommodation to them, by meeting the market competition criteria being permanently better than the competitors" (Czako 2005).

\section{Components of the corporate competitiveness (second level)}

Determining the components of competitiveness means the second level of interpreting the competitiveness. In the specialized literature, the components of corporate competitiveness can be grouped around the following 4 approaches:

- industry approach; 
Nagy T. O., Darabos E., Labas I., (2016)

Measuring methods of the corporate competitiveness, and those weaknesses

- resource-based approach;

- enterprise-sided approach;

- financial approach.

The industry approach applies the five-factor model as a framework at corporate level. The model has identified 5 models which are basically influencing the strategy that can be applied in the particular industry. These factors are shown by the following figure (1.).

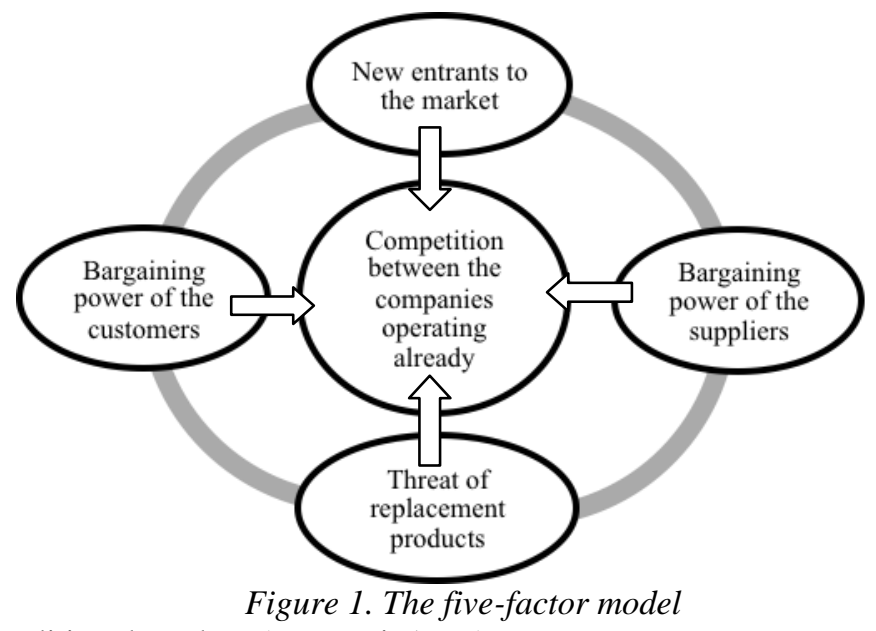

Source: Own edition, based on (Hovanyi, 1999)

According to the five-factor model, the corporate performance is composed of two separate parts: in one respect, the activities being usual in the industry, on the other hand, those activities that, beyond these, the company can carry out above the average (Porter, 1979). The company needs the activities being usual in the industry in order to be able to start in the competition at all. At the same time, it does not still mean a competitive advantage in itself. Only those activities mean competitive advantage that the enterprise will be able to carry out above the average.

The resource-based approach has brought new aspects regarding the corporate inputs into the examination of corporate competitiveness. The resources possessed by the enterprise have decisive importance in evolving the competitiveness - this is the main statement of those who adhere to the theory. It is important that these resources should be valuable, infrequent, difficult to copy difficult to replace, heterogeneous and immobile. The fact that what type of, what amount of and what quality of resources the company possesses is determining what potential opportunities the company can select from at all. At the same time, it is at least as 
important that the resources possessed can be utilized only in case of a good strategy and an organization being able to fulfil the strategy successfully.

The enterprise-sided approach is another ramification of the train of thoughts which has attracted attention to the role of environment. There is an important statement of the authors that the enterprise qualitatively means something different than the self-employment. According to whether the given enterprise contributes to the social welfare, productive, unproductive and destructive enterprises are differentiated. The enterprise-sided approach introduces the concept of "highimpact entrepreneurships. These are innovation-driven enterprises, "high-growth companies" operating in a very uncertain environment which are going on an extraordinary growth path. Based on this, the variables concerning the growth and internationalisation have place in a competitiveness model and in a measurement based on that.

The fourth and final discussed competitiveness approach is the financial approach. However, this was emphatically not the original intention of the cited authors but the Balanced Scorecard flashes the possibility of competitiveness measurement. BSC groups its message around four equal aspects (financial aspect, customer aspect, learning and development, operational processes) and it gives opportunity to connect the "hard" (more financial-based) and the ,soft" (more corporate governance perspective) areas with each other. Based on this, beyond the financial variables, the variables relating to the individual and organizational development have also place in a competitiveness model and in a measurement based on that.

\section{Empirical examination of the corporate competitiveness (third level)}

Overall, we can find more widely quoted indices at national (macro) level (e.g. GCI, IMD etc.), we can rather read about theoretical models at regional (mezo) level while the research of corporate level (micro level) is still sporadic even in the international specialized literature.

The competitiveness performances of companies are basically modelled by taking the national and local environments into consideration (Nelson, 1992). According to this, the performances of enterprises operating in a particular region are principally determined by peculiarities of the industry. However, it is important to emphasize that, in case of these types of treatises, the calculation is performed with aggregated data which cannot explain the performance differences of companies within the industry. By means of the aggregated calculation, the treatises could result in false conclusions as well as these ones ignore the internal factors of corporations. The domestic corporate competitiveness researches are principally focusing on the institutional factors (e.g. Hovanyi, 1999).

However, there are such international treatises which are just focusing on the internal characteristics. Barney mentions four features of the individual resources 
such as valuability, rarity, imperfect reproducibility, substitutability (Barney, 1991). The device mentioned by Barney may materialize into numerous forms such as knowledge, information and capacity. If the resources have unique peculiarity, there will be an opportunity for the enterprise to ensure the profitability and competitive advantage above the average. However, the possession of these resources and the advantageous market situation do not automatically determine the success function-like at all. A successful enterprise is supported by a successful strategy and by an organization that is able to carry out the strategy.

Another deficiency of the competitiveness research is that a large part of the analyses is concentrating on the multinational companies (e.g. Chikan, 2006; Porter, 1998). Its cause is supposedly the statement of Porter that it is worth examining the competitiveness in such a sector where the given country has a comparative advantage. In the theory of Porter, the size economy, technology, existence of the large and strongly segmented domestic market as well as the multinationality are extremely important in establishing and maintaining the competitive advantages of the large companies. The strategic literature also concerns the level of large companies (Ansoff, 1957; Chandler, 1962; Porter, 1996), in which massive organizations possessing huge resources to such an extent that certain authors (Kotler, 2000), taking it from the military services, are describing the situation as tense relations between two armies and they are speaking about, for example, front attack or pre-emptive strike.

However, the sector of small- and medium-sized enterprises has a huge importance in Hungary. Based on the data of KSH (the Hungarian Statistics Office) from 2014, $99.95 \%$ of the registered economic organizations belong to the sector of small- and medium-sized enterprises, $97.89 \%$ of these enterprises are microenterprises. The role of SME sector in the employment is also extremely significant. The organizations employing maximum 249 persons employed almost 2 million employees in total in 2014 which was $73 \%$ of headcount of the corporate sector. Due to their numerical dominance, the role of microenterprises employing maximum 9 persons is the most crucial viz. These enterprises have provided income for more than half of the persons employed by the SMEs. Their significance will presumably continue to grow since the annual growth regarding the number of organizations primarily results from the rise in number of the selfemployed persons. Namely, in the researches concerning the corporate competitiveness, we can hardly avoid modifying the statements about the strategy and the associated competitiveness that is significantly compared to the standard literature based on large companies. Regarding the measurability, there is a separate problem that the uniqueness is the key factor to the success in case of SMES (Porter, 1979) and the uniqueness is hardly measurable directly. One of the possible solutions for the problem is that we try to identify such factors which can 
be the mappings of this "uniqueness representing success"; such ones whose existence clearly refers to the competitiveness based on the formal logic. Despite the indisputable importance of the competitiveness of SME sector, such models are rarely created in practice for measuring the competitiveness of the small- and medium-sized companies. Usually, the corporate competitiveness is examined by means of the criteria set established by the same competitiveness definition, not focusing on the specific features of SMEs. While I was researching the specialized literature, I discovered a treatise of Laszlo Szerb which focuses on the internal factors and dispenses with the examination of effects of the institutional and other environmental factors during the examination of competitiveness of the small- and medium-sized enterprises (Szerb, 2010). During the modelling, Laszlo Szerb took perhaps the fullest corporate competitiveness definition created by Erzsebet Czako for a basis. According to this the definition, he determined the factors of corporate competitiveness in a unit of the physical and human resources, networking, ability to innovate and the administrative routine elements. In case of determining the appropriateness of elements, he rejects the calculation based on average and weighed average because thus he would ignore the fact that the elements are interconnected i.e. these could weaken or fortify each other. In the model, he applies the principle of the weakest link, namely, the weakest element has a negative effect on the other factors. In case of corporations with different competitiveness, the method is suitable for determining the strategicdevelopmental guidelines as well. However, it may be required to separate the industry standards since the competitiveness may significantly be different in the areas.

The next important chapter of the treatise expounds the author's competitiveness research concerning the micro and small enterprises. My research had a benchmark nature, it aims to ensure a basis for comparison of subsequent queries and researches; its goal is to present how the respondents opine on the competitiveness of their companies. In my research I have sought to find out which external and internal factors are decisively influencing the competitiveness of the Hungarian micro and small enterprises.

\section{Materials and methods}

The research was based on a database resulting from a primer data collection closed at the end of 2015 which had been aimed at surveying the competitiveness of micro and small enterprises as well as exploring the external and internal factors influencing their competitiveness. The database contains data concerning 102 members of the Chamber of Trade and Industry of Hajdu-Bihar County, the query of data was performed by the help of a questionnaire containing 12 questions. A total of 634 questionnaires were sent out electronically, the rate of return was $20 \%$, 
128 pieces of the questionnaires sent out were returned. 26 pieces of the returned questionnaires could not be evaluated so the final element number of the sample is 102.

By possessing the address list, I had the opportunity to apply a sampling procedure based on chance; however, we cannot speak about the other pillar of scientific sampling i.e. the representativeness since the element number of the sample resulting in the final outcome is inadequate.

According to the data of Central Statistical Office regarding November of 2015, the number of business associations having legal personality was 550007 pcs in Hungary, 399039 (72.6\%) of them operated in form of Ltd., $140763(25.6 \%)$ in form of limited partnership, $6284(1.1 \%)$ in form of Inc., and $3921(0.7 \%)$ in form of general partnership. The resulting corporate sample does not reflect the rates being peculiar to the examined population representatively as it is illustrated by the chart below.

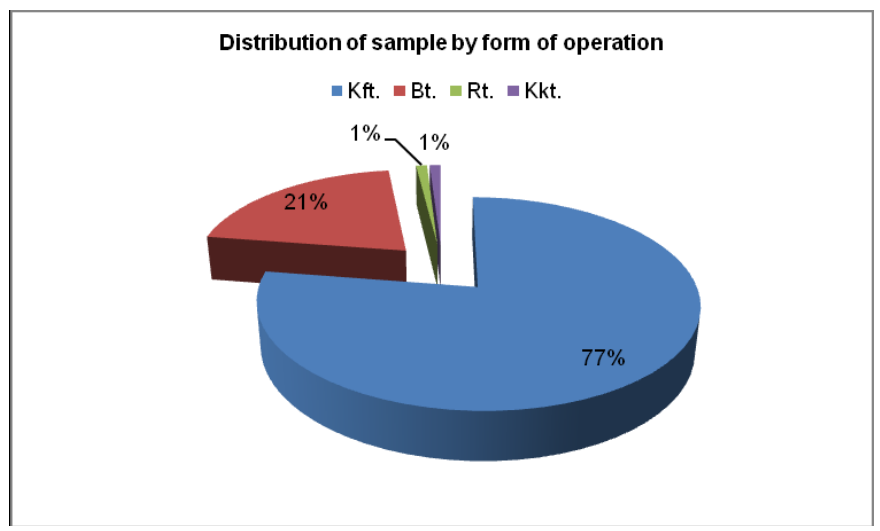

Chart 1. Distribution of sample by form of operation

Source: Own edition, based on data resulting from the research

$77 \%$ of the enterprises in the sample operate as Limited Liability Company and $21 \%$ as limited partnership. One general partnership and one incorporated company got into the sample, representing a 1-1\% rate. Namely, the business associations operating in form of Ltd., as well as general partnership are slightly overrepresented and the ones operating in form of limited partnership and Inc., are slightly underrepresented.

The (2.) chart below shows the distribution of companies included into the sample by statistical staff headcount. 
Nagy T. O., Darabos E., Labas I., (2016)

Measuring methods of the corporate competitiveness, and those weaknesses

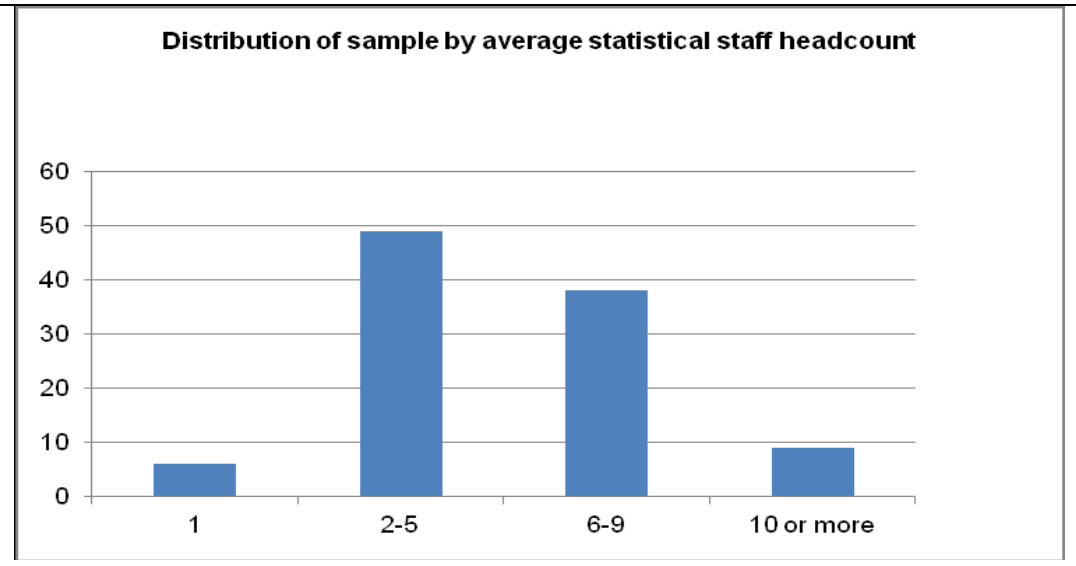

Chart 2. Distribution of sample by average statistical staff headcount

Source: Own edition, based on data resulting from the research

In the way as it can be seen on the diagram, I formed headcount categories with separations of 1 head, 2-5, 6-9, 10 or more heads. The fragmentation being peculiar to the Hungarian can be observed in the sphere of companies filling in the questionnaire as well since the mean of the average statistical staff headcount was 4.9 heads in the sample.

By examining the companies based on their net sales revenues concerning the year of 2014, it can be seen well that $55 \%$ of them belong to the category between HUF 5000000 and 49999000 . As diagram 3 shows, only 15\% of the companies reached higher net sales revenues.

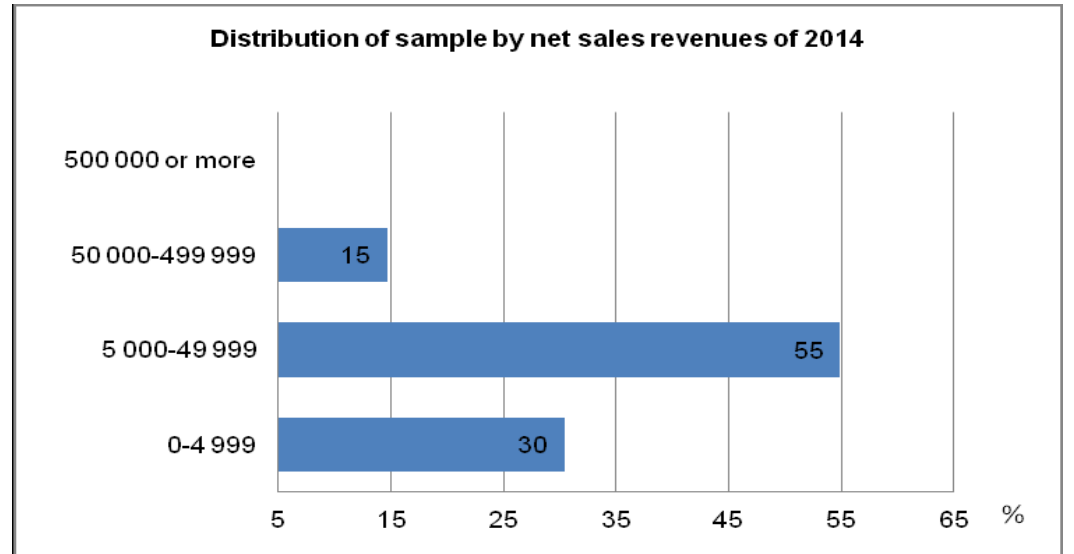

Chart 3. Distribution of sample by net sales revenues of 2014

Source: Own edition, based on data resulting from the research 
The processing of questionnaires was carried out by means of the program package SPSS, by applying the following statistical methods: absolute and relative frequency rows, descriptive statistical indicators as well as hypothesis examining procedures characterizing the relation of criteria. I analysed the relation of the company size (as a non-metric independent variable) and the other variable (as dependent variable) by two types of method. If the dependent variable was also a non-metric variable then I performed an independence examination $\left(\chi^{2}\right.$-test $)$ and if it was a metric one then I made a variance analysis (F-test). Since, in case of these hypothesis examination procedures, the null hypothesis is always that the independent variable does not influence the development of the dependent variable. The ' $p$ ' values reported by SPSS are also indicating the smallest significance level where the null hypothesis can already be rejected; therefore I evaluated the result as a significant coherence only when ' $p$ ' was $\leq 0.05$. I examined the strength of associative relations proved to be significant by means of Cramer's indicator; its value can vary between 0 and 1 and its bigger value refers to a closer relation. In case of significant mixed relations, I applied the variance quotient for measuring the closeness of relation which can also take a value between 0 and 1 and it shows the percentage of the variance of the dependent variable and how it is explained by the independent variable (Hunyadi - Vita 1992).

\section{Results}

On the resulting sample, I examined the closeness of relation of the business form and the average statistical headcount. Based on the calculations, only that relation can be set forth which is weaker than medium and has a positive direction. Namely, a typical headcount extent cannot clearly be associated with the business forms but it can be stated that an above-average headcount extent is peculiar to the limited liability companies while a below-average one is typical of the limited partnerships. The average net sales revenue is HUF 78.458 thousand but its median value is low enough i.e. HUF 18.235 thousand. The average is significantly improved by the corporations performing better. This result can also be explained by the relation with strong positive direction between the headcount and the net sale revenue i.e. the companies having a bigger headcount can reach higher net sales revenue.

The first, competitiveness question of the questionnaire applied to how the entrepreneurs adjudge the development of competitiveness of their own firms in the last 5 years (between 2011 and 2015). Distribution of the answers is illustrated by the diagram below. 


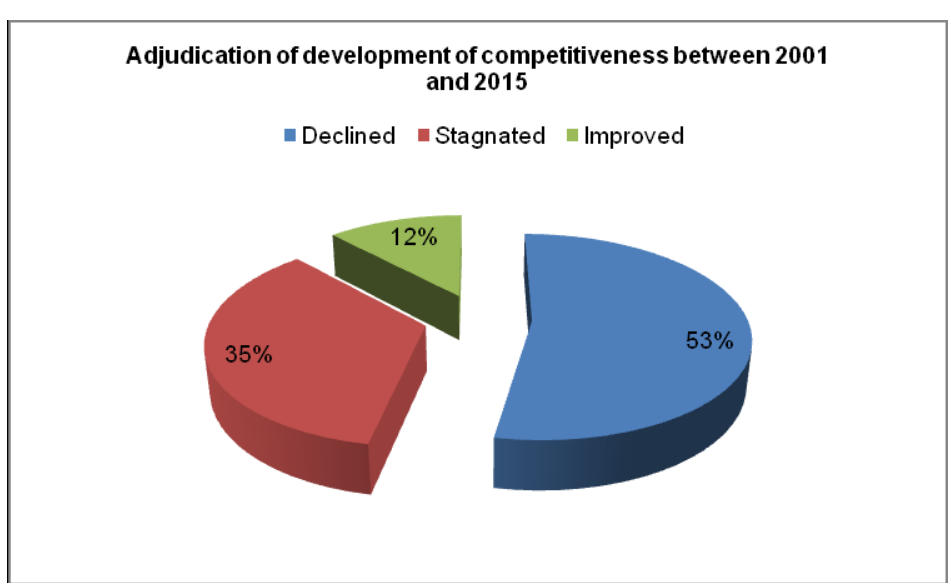

Chart 4. Adjudication of development of competitiveness between 2001 and 2015 Source: Own edition, based on data resulting from the research

More than half of the entities filling in the questionnaire think that their companies are less competitive today than five years ago. 35\% of them opined that their competitiveness had not changed during these five years while only $12 \%$ of them expressed positive opinion about the development of competitiveness of their firms. Based on our analyses, we can say that only $5.3 \%$ of the enterprises employing less than 25 persons declared positively while $78 \%$ of the ones employing more than 25 persons stated that their competitiveness had improved. The survey shows that there is a positive correlation between the size of companies and the preservation of their competitiveness as well as the improvement of their competitiveness.

My further questions were aimed at mapping the factors influencing the competitiveness. On the next (5.) diagram, those factors have been indicated which are mostly hindering the competitiveness in the entrepreneurs' opinion.

According to $25.5 \%$ of the respondents, the competitiveness of general partnerships is influenced (in a negative sense) to the greatest extent by the high public charges on the wages. $22.5 \%$ of the companies marked the unpredictability of tax system as the factor mostly hindering the competitiveness. This factor indirectly appears in the high value related to the legal uncertainty as well. Namely, these three factors are considered to be mostly responsible for the inadequate competitiveness. Outstanding values are also relating to mistrust; the enterprises trust neither each other nor the state. The enterprises need to spend serious additional expenditures in order to compensate this lack of confidence; all these expenditures damage the cost-effectiveness and, through this, their competitiveness. 
Nagy T. O., Darabos E., Labas I., (2016)

Measuring methods of the corporate competitiveness, and those weaknesses

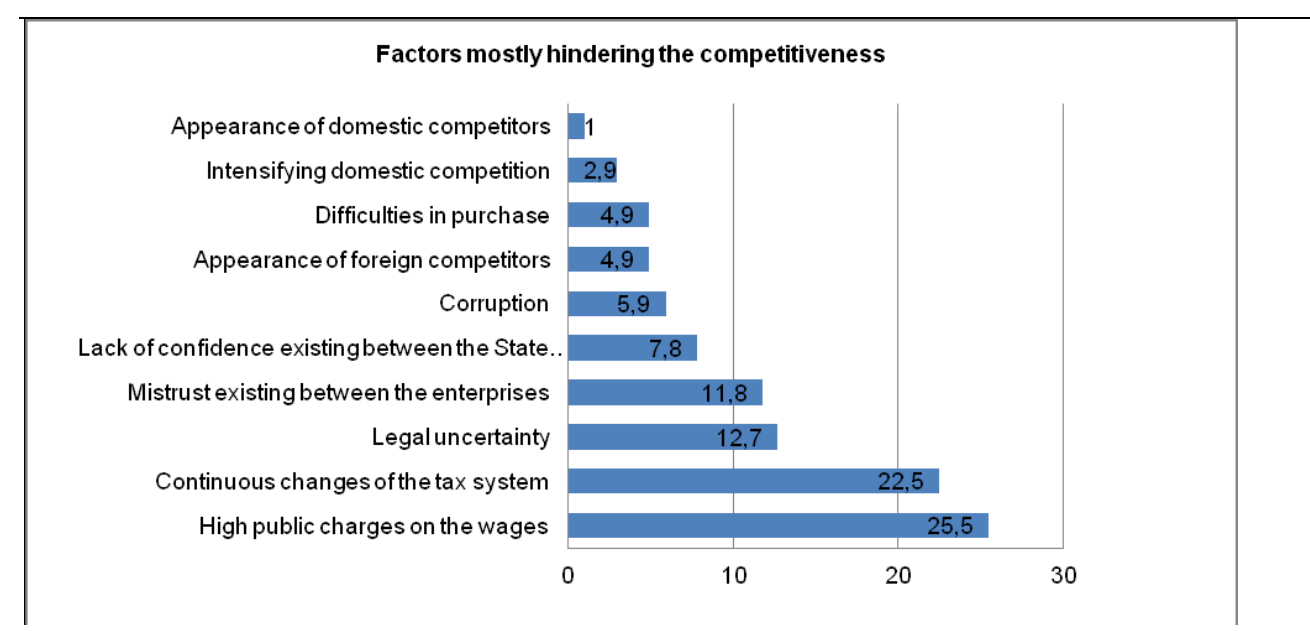

Chart 5. Factors mostly hindering the competitiveness

Source: Own edition, based on data resulting from the research

The high assessment (5.9\%) of corruption as a factor negatively influencing the competitiveness is typical as well. It is interesting that few companies regarded the appearance of competitors as a dangerous factor on their firms. It may occur that they did not sense the intensification of their competitors or they regarded the growing competition as an incentive for increasing the competitiveness of their firms. During my analysis, it was also conspicuous that the mistrust existing between the enterprises was better highlighted by the companies with lower sales revenues and the difficulties in purchase are bigger problem in the sphere of firms with higher sales revenues.

As a counter pole, I questioned what they regarded as a sine qua non of the competitiveness of enterprises.

Most of the respondents marked the accumulated experience as a factor mostly influencing the competitiveness. The experience is really extraordinarily important since the micro and small enterprises are more exposed to the external factors than the medium sized ones or the large companies; the experience significantly facilitates to face competition. Also, the respondents considered the following things important: the owners' expertise and commitment as well as the factor that an owner should have extensive business relations. It is worth watching the correlation between the factors of competitiveness and the headcount, the companies with lower headcount preferably regarded the commitment of owners as the main source of their competitiveness while the enterprises with higher headcount indicated the effect of employees' commitment on the competitiveness in greater numbers. 
Nagy T. O., Darabos E., Labas I., (2016)

Measuring methods of the corporate competitiveness, and those weaknesses

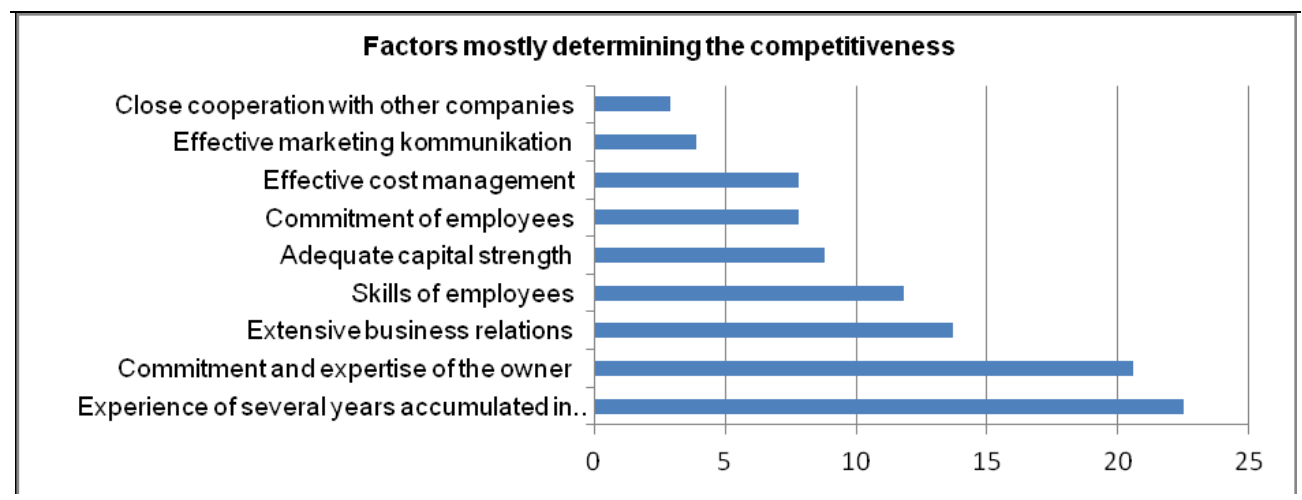

Chart 6. Factors mostly determining the competitiveness

Source: Own edition, based on data resulting from the research

The higher sales revenue on a 10-percent significance level was expounded by the fact that the company regarded the commitment or expertise of employees as a sine qua non of its competitiveness. Inconsiderable enterprises highlighted the marketing; its explanation of a certain kind may be that the micro and small enterprises do not possess enough capital to utilize effective marketing tools. The close cooperation with other companies was the least emphasized; this suggests that the networking is very rare in the sphere of micro and small enterprises in our country. During my research, I was curious about the relationship between enterprises, about their business; the following questions applied to the numbers of competitors, suppliers as well as customers. Most firms have 6 or more competitors; it is very rare (3\%) that a company carries out such an activity which is performed on the market by no one else. The following diagrams $(7 ., 8$.) show the number of business relationships from input as well as output side.

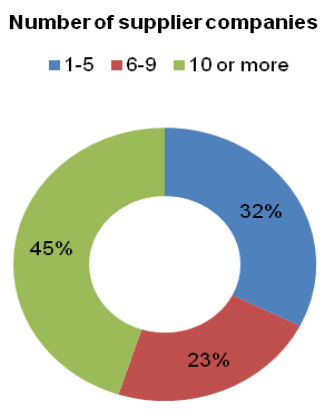

Chart 7. Number of supplier companies

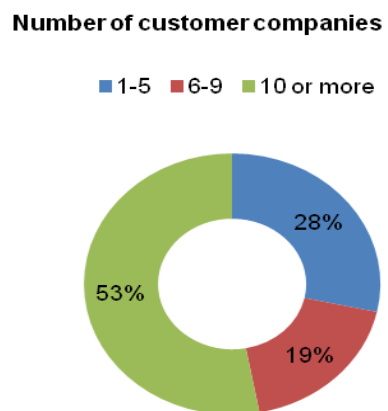

Chart 8. Number of customer companies Source: Own edition, based on data resulting from the research 
Based on my analysis, it can be proved that a bigger number of business relationships have unequivocally positive effect on the sales revenues.

The next examined viewpoint was whether the given companies carried out export activity. 82 of the responding companies (80.4\%), do not export at all, they are not able to appear on the international markets. One reason could be the competitiveness of small enterprises, lagging behind large companies and it deepens further due to the fact that small enterprises are left out of the international competition since the coping with foreign markets may have an incentive effect on the development of firms and the improvement of their competitiveness. My most important conclusion drawn during my research applies to the extremely close and positive relation existing between the competitiveness and export activity. Namely, there is a significant difference in the results of exporting and non-exporting companies, the exporting ones reach far higher sales revenue compared to the nonexporting ones, most of them already belong to the category of small enterprises. Besides, they have a more extensive network of contacts; they have regular business relations with several suppliers and customers. A more stable performance is also revealed by the leaders of exporting companies who adjudge the changes in the competitiveness of their firm in a more positive way than the leaders of nonexporting ones. It is buttressed up by the fact that the companies having more than 25 employees forecasted an improvement in their competitiveness. As a consequence of bigger size and better performance, the exporting companies sense fewer competitors on the market than the non-exporting ones. From the point of view of their competitiveness, the exporting companies considered the following things much more important than the non-exporting ones: close cooperation with other companies, adequate capital strength and marketing. In addition, the exporting companies regard the legal uncertainty as well as the lack of confidence existing between the economic operators and the state as bigger problems.

\section{Summary}

In both the international and Hungarian specialized literature, we can find such treatises which successfully seize the corporate competitiveness and such researches which successfully measure the corporate competitiveness from some point of view but the science has yet to work out a model which can fully measure the competitiveness of companies of SME sector.

Numerous competitiveness researchers think that, beside the international huge corporations, the companies of SME sector are the ones that possess such competitiveness sources which are sustainable on the long term and can be copied with difficulty. They emphasize more and more that the competitiveness of the small and medium-sized enterprises is crucial from the point of view of the regions' and national economies' competitiveness. Of course, these two sectors are 
completely different so the criteria of competitiveness should be different as well. The sources of competitiveness of the micro, small and medium-sized companies may be the following during an operative time period: accommodation to the customer demands as fully as possible, creating reasonable prices, utilizing the advantages of group work; and during a strategic time period, sensitivity for the environmental impulses and the ability to respond without any delay, enhancement of the professional skills and preservation of the flexibility. On the contrary, the following things express the competitiveness criteria of the international huge corporations: during an operative time period, the adequacy of difference between returns and expenses which is weighed by risk and the utilization of the local possibilities of result increasing; and during a strategic time period, keeping abreast of the global technical progress, financial stability, appropriate international market share as well as utilization of opportunities arising from the local competitive advantages. So, it is obvious that the competitiveness of these two sectors cannot be measured based on the same criteria, competitiveness system of index numbers. The starting point of working out a new system measuring the corporate competitiveness is the identification of corporate competitiveness and its key factors. The corporate competitiveness cannot suitably be measured without defining what we mean by the corporate competitiveness and what key factors the definition can be split into. By splitting the key factors into elements, we obtain such smaller units which can be measured by index numbers. The competitiveness can be concentrated to one number by means of the scales assigned to index numbers and by weighing.

The definition determined by the already-mentioned Competitiveness Research Centre can mean the basis of SME sector's competitiveness measurement but not by itself, without additions and modifications. However, one of the EU's most important targets is to make the operation of small and medium-sized enterprises international but, in this corporate circle, the deciding factor is to withstand the competition in domestic markets, with domestic operators, in numerous cases. Their competitiveness primarily manifests itself in the extent to which they are able to utilize the flexibility and adaptability arising from the organizational size.

I believe that the survey performed by me could be a good starting point for further research. The following things could be a possible direction to continue: extending the questionnaire to further chambers as well as harmonizing the questionnaire with data for example from the Opten database, by means of which I could analyse the performance indicators of the same companies from which I received personal opinions about the factors determining their competitiveness. I think it is important to examine such areas that I have not been able to investigate yet due to the time limits of the research. Such directions or areas of research refer to the examination 
of the relationship between innovation activities of companies, skills of employees and competitiveness.

\section{References}

1. Ansoff, H. I. (1957). Strategies for Diversification. Harvard Business Review, vol. 35, no. 5, pp. 113-124.

2. Barney, J. B. (1991). Firm resources and sustained competitive advantage. Journal of Management, vol. 17, no. 1, pp. 99-120.

3. Chandler, A. D. (1962). Strategy and Structure: Chapters in the History of the American Industrial Enterprise. MIT Press. Cambridge, p.490

4. Chikan, A. (2006). A vallalati versenykepesseg merese. Penzugyi Szemle, vol. 51, no. 1, pp. 42-54.

5. Czako, E. (2005). Versenykepessegi programok nehany tanulsaga a kormanyzati szfera szamara - az Ir Versenykepessegi Tanacs es a Lisszaboni Strategia, Versenyben a Vilaggal 2004 - 2006. 11. sz. mühelytanulmany. Versenykepesseg Kutato Kozpont. Budapest, p. 34

6. Csaba L. (2008). Versenykepesseg - hitek es balhitek. Debreceni Szemle, vol.16, no. 2, pp.162-173.

7. Csorba, L. (2009). Vazlat a verseny es versenykepesseg fogalmi tisztazasahoz. Kezirat, Kutatasi forum 2009. junius 18-20. Debreceni Egyetem, Kozgazdasagtudomanyi Doktori Iskola.

8. Horvath, Gy. (2001). A magyar regiok es telepulesek versenykepessege az europai gazdasagi tersegben. Ter es Tarsadalom, vol. 15, no. 2, pp. 203-231.

9. Hovanyi, G. (1999). A vallalati versenykepesseg makrogazdasagi es globalis hattere - Michael Porter ket modelljenek tovabbfejlesztese. Kozgazdasagi Szemle, vol.46, no. 11, pp. 1013-1029.

10. Hunyadi, L., Vita, L. (2008). Statisztika 1. Aula. Budapest, p. 348

11. Kotler, P. (2000). Marketing management. Prentice-Hall. New Jersey, p. 788

12. Lengyel, I. (1999). Regiok versenykepessege (A tersegek gazdasagfejlesztesenek főbb kozgazdasagi fogalmai, alapgondolatai, tenyezői az EU-ban). Kezirat. JATE Gazdasagtudomanyi Kar. Szeged, p. 66

13. Meyer-Stamer J. (2008). Systematic Competitiveness and Local Economic Development, Retrieved from: http://www.meyer-stamer.de/2008/Systemic+LED_ SouthAfrica.pdf

14. Nelson, R. (1992). Recent Writing on competitiveness: Boxing the compass. California Management Review, vol. 34, no. 2, pp. 127-137.

15. Porter, M. E. (1979). How competitive forces shape strategy. Harvard Business Review, vol. 57, no. 2, pp. 137-145.

16. Porter, M. E. (1996). What is strategy? Harvard Business Review, vol. 74, no. 6, pp.61-78. 
Nagy T. O., Darabos E., Labas I., (2016)

Measuring methods of the corporate competitiveness, and those weaknesses

17. Porter, M. E. (1998). On competition. Harvard Business School Press. Boston, p. 320

18. Porter, M. E., Schwab, K. (2008). The global competitiveness report 20082009. World Economic Forum Geneva, p. 500

19. Schatzl, L. (1993). Wirtschaftsgeographie der Europaischen Gemeinschaft. Schoningh Verlag. Stuttgart, p. 224

20. Szerb, L. (2010). A magyar mikro-, kis- es kozepvallalatok versenykepessegenek vizsgalata. Vezetestudomany, vol. 41, no. 12, pp. 20-35. 21. Torok, A. (1999). A versenykepesseg egyes jogi es szabalyozasi feltetelei Magyarorszagon. Kozgazdasagi Szemle, vol. 54, no. 12, pp. 1066-1084. 